\title{
Erythromycin levels within eggs and alevins derived from spawning broodstock chinook salmon Oncorhynchus tshawytscha injected with the drug
}

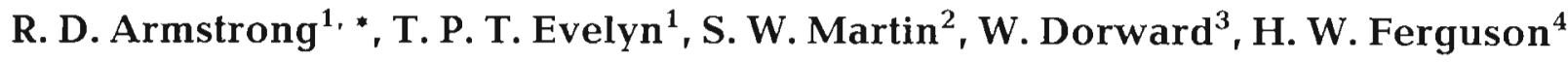 \\ ${ }^{1}$ Dept of Fisheries and Oceans, Biological Sciences Branch, Pacific Biological Station, Nanaimo, British Columbia, \\ Canada V9R 5K6 \\ ${ }^{2}$ Dept of Population Medicine, Ontario Veterinary College, University of Guelph, Guelph, Ontario, Canada N1G 2W1 \\ ${ }^{3}$ Health of Animals Laboratory, Agriculture Canada, Richmond, British Columbia, Canada V6X 2T4 \\ ${ }^{4}$ Dept of Pathology, Ontario Veterinary College, University of Guelph, Guelph, Ontario, Canada N1G 2W1
}

\begin{abstract}
This study was conducted as part of a field trial to evaluate procedures used for control of vertical transmission of Renibacterium salmoninarum in chinook salmon in a hatchery in British Columbia. Erythromycin levels in ovarian fluid, eggs and sac fry were measured following injection of the drug at a dose of $20 \mathrm{mg} \mathrm{kg}^{-1}$ into the 'dorsal sinus' of female broodstock just before spawning. Significant drug levels were achieved in eggs following treatment as little as $9 \mathrm{~d}$ before spawning, and these persisted, in decreasing levels, until the external yolk sac had been completely resorbed by the developing alevin. Drug levels in ovarian fluid declined to below detectable limits within $20 \mathrm{~d}$ after injection.
\end{abstract}

\section{INTRODUCTION}

Bacterial kidney disease $(\mathrm{BKD})$ is caused by the small gram-positive bacillus Renibacterium salmoninarum. This bacterium is known to be transmitted vertically (Bullock et al. 1978) and it has been shown that this can occur as a result of the presence of the organism within the salmonid egg, escaping the effects of surface disinfectants (Evelyn et al. 1984a, b, 1986c). Erythromycin has been recommended as an appropriate chemotherapeutic agent for the suppression of $R$. salmoninarum (Austin 1985). This antibiotic has also been evaluated as a method of controlling vertical transmission of this bacterium, although it has not been successful for water-hardening eggs (Evelyn et al. 1986a, b), or for the treatment of diseased fish (Evelyn 1988).

Groman \& Klontz (1983) injected erythromycin into the 'dorsal sinus' of female chinook salmon broodstock. They found that the drug was present within the yolk

\footnotetext{
- Present address and address for reprint requests: Dept of Pathology, Ontario Veterinary College University of Guelph, Guelph, Ontario, Canada N1G 2W1
}

material of eggs from injected fish, but that it did not persist there for more than $24 \mathrm{~h}$ following water hardening. In contrast, Bullock \& Leek (1986) showed that the drug could persist within the yolk material of eggs and fry from injected chinook salmon for as long as $70 \mathrm{~d}$ post-spawning. In both of these experiments the fish were injected with a dose of $11 \mathrm{mg} \mathrm{kg}^{-1}$ body weight at least $30 \mathrm{~d}$ prior to spawning. Evelyn et al. (1986b) injected female coho broodstock Oncorhynchus kisutch with erythromycin at $20 \mathrm{mg} \mathrm{kg}^{-1}$ into the dorsal sinus. They also found that drug levels persisted within the yolk material of eggs in spite of water hardening. By varying the time of injection before spawning, it was also shown that injection more than $70 \mathrm{~d}$ before spawning did not result in detectable drug levels in yolk material. In 1 fish which was injected only $13 \mathrm{~d}$ before spawning, drug levels were detected in the yolk (Evelyn 1988), and measured levels exceeded $0.3 \mu \mathrm{g} \mathrm{ml}^{-1}$, their reported in vitro minimum inhibitory concentration (Evelyn et al. 1986b).

Many private salmon hatcheries in British Columbia have adopted the erythromycin injection procedure for their broodstock as part of an armamentarium of 
techniques for controlling vertical transmission of Renibacterium salmoninarum within the salmonid egg In spite of these attempts to control the disease, vertical transmission remains a problem at one groundwatersupplied hatchery. A field trial was designed to evaluate the methods of control used, including the injection of erythromycin. This paper reports new information, gathered during the course of the trial, on the levels of the drug attained in coelomic fluid, eggs, and fry following the injection procedure.

\section{MATERIALS AND METHODS}

For this trial 3003 -yr-old domestic female chinook Oncorhynchus tshawytscha broodstock, which had not received any prior antibiotic treatment, were provided by a private hatchery. Over a period of $2 \mathrm{~d}$ in early October 1987, the fish were transferred in small groups by helicopter from the salt water pens to the fresh water hatchery. As each load arrived, the fish were individually given numbered tags and injected with erythromycin (Erythro ${ }^{\circledR}-200$, Abbott Laboratories) at $20 \mathrm{mg} \mathrm{kg}^{-1}$ into the dorsal sinus. The injection was sequentially withheld from every 5 th female fish to systematically obtain a randomly uninjected control group. Hatchery staff were kept uninformed as to the injection status of each fish. Both injected and uninjected fish were held together in circular tanks and supplied with aerated groundwater at $10^{\circ} \mathrm{C}$.

The pens were checked regularly and fish were removed for spawning when ready. Samples of eggs and ovarian fluid were then collected for analysis of erythromycin levels. Drug levels were assayed using the cylinder plate method (Difco 1968) as modified by Evelyn et al. (1986b). The contents of yolk material from 5 different eggs and at least 2 samples of ovarian fluid were assayed and averaged to obtain the result for each fish.

To assess the change in erythromycin levels in yolk material during incubation, embryonated eggs were sampled at ca $75 \mathrm{~d}$ after spawning from those incubation trays in which the hatchery had kept the offspring of a single broodstock fish. The yolk material was aspirated from these samples with a $20 \mathrm{~g}$ hypodermic needle attached to a $3 \mathrm{cc}$ syringe, and erythromycin levels assayed as described above. In addition, several hundred embryonated eggs from 1 injected and 2 uninjected fish were returned to the laboratory where they were incubated and hatched. Samples of yolk material were aspirated from alevins hatched from these eggs for measurement of drug levels at 116, 123, and $141 \mathrm{~d}$ following injection. The last sample was taken just before the alevins' yolk sacs could no longer be seen on external examination.

\section{RESULTS}

Erythromycin within the yolk of eggs (Fig. 1) from females injected as little as $9 \mathrm{~d}$ before spawning exceeded the in vitro inhibitory levels reported by

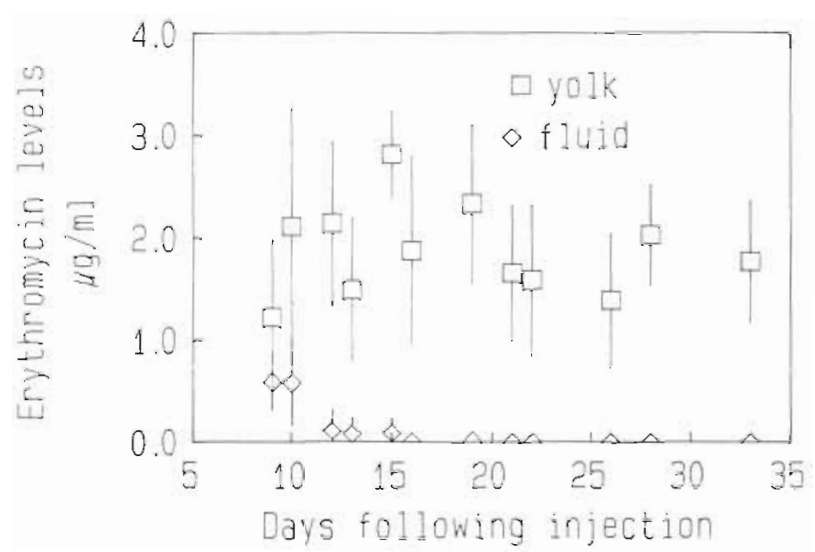

Fig. 1. Oncorhynchus tshawytscha. Erythromycin levels in yolk and ovarian fluid following broodstock injection. Bars = standard deviation

Evelyn et al. (1986b). There was moderate variation in drug levels between individuals injected at each time period (standard deviation bars, Fig, 1), but this variation was consistent over the course of the trial. Yolk erythromycin levels measured at 68 and $75 \mathrm{~d}$ postinjection had decreased, on average, to ca $65 \%$ of the level within the yolk material of eggs at spawning (Table 1). However, the measured levels remained

Table 1. Oncorhynchus tshawytscha. Decrease of erythromycin levels in yolk taken from incubating embryonated eggs spawned from injected 3-yr-old female chinook salmon

\begin{tabular}{|c|c|c|}
\hline $\begin{array}{l}\text { Days following } \\
\text { injection }\end{array}$ & 68 & 75 \\
\hline $\begin{array}{l}\text { No. of brood fish } \\
\text { sampled }\end{array}$ & 6 & 19 \\
\hline $\begin{array}{l}\text { Mean erythromycin level } \\
\text { (ug ml-1) }\end{array}$ & $1.31 \pm 0.41^{\mathrm{a}}$ & $1.26 \pm 0.25$ \\
\hline $\begin{array}{l}\text { Mean percentage of erythro- } \\
\text { mycin level at spawning (\%) }\end{array}$ & $65 \pm 18^{b}$ & $67 \pm 11$ \\
\hline $\begin{array}{l}\text { a Standard error } \\
\text { b Standard deviation }\end{array}$ & & \\
\hline
\end{tabular}

higher than $0.3 \mu \mathrm{g} \mathrm{ml}^{-1}$, the reported in vitro minimum inhibitory concentration (Evelyn et al. 1986b). To show the decrease in drug levels during incubation, results from incubating embryonated eggs are presented as a mean percentage of the level measured in the yolk material of eggs from the same fish at spawning (Table 1). In addition, drug levels were detected within yolk 
material aspirated from laboratory-hatched alevins shortly before closure of the abdominal cavity, $141 \mathrm{~d}$ after injection. These had decreased to less than half the level measured in egg yolk material from the same female at spawning, but were still greater than $0.3 \mu \mathrm{g}$ $\mathrm{ml}^{-1}$

In contrast to the persistance of erythromycin in the yolk material, drug levels dropped rapidly in the ovarian fluid from injected fish (Fig. 1). No antimicrobial activity was found in ovarian fluid from fish which had been treated more than $20 \mathrm{~d}$ before spawning. No evidence of any antimicrobial activity was found in samples of fluid, eggs, embryonated eggs or alevins from the control group of uninjected female broodstock.

\section{DISCUSSION}

These results confirm the work by Bullock \& Leek (1986) and Evelyn et al. (1986b) on the persistence of erythromycin within the yolk material of eggs from injected fish. Furthermore, because the drug persists at inhibitory levels within yolk material from just after injection of the brood fish until 'button up' of the alevin it will probably be effective in controlling intra-ovum Renibacterium infections. Although results from the alevins of only 1 fish are reported in this paper, examination of alevin yolk material from injected broodstock from other hatcheries also showed drug levels greater than $0.3 \mu \mathrm{g} \mathrm{ml}^{-1}$. These measurements are not included because the dates of injection and spawning could not be confirmed for each broodstock fish.

Hatcheries would like to minimize the time that broodstock spend in fresh water before spawning, in order to reduce broodstock mortality. These data show that even if the time of transfer is delayed until $9 \mathrm{~d}$ before spawning, the injection will still provide levels of the drug likely to be of therapeutic value. In addition, only 1 treatment is required to achieve effective levels so that the handling stress on the fish can be reduced by treating only at the time of transfer. The mean level of drug achieved within the eggs was relatively unaffected by the time between injection and spawning, although the highest egg drug levels were achieved when this period was between 12 and $20 \mathrm{~d}$.

The decrease in drug levels within ovarian fluid, while yolk levels remained high, shows that the drug has been sequestered within the yolk material. This might be due to association of the drug with lipoprotein molecules that are entering the oocyte via micropinocytosis in association with vitellogenesis (Wallace 1978). An alternative, and perhaps more likely hypothesis considering the timing of the injection, is that erythromycin is entering the egg as a soluble component of the water taken up during the final maturation process (Riazi \& Fremont 1988). Whatever the mechanism, it does not inhibit the antimicrobial activity of the erythromycin, as drug levels within the egg were measured with a microbiological assay

The possibility still remains that some of the bacteria responsible for vertical transmission of $B K D$ in the hatchery could be on the surface of the egg, as postulated by Bruno et al. (1986), thereby avoiding the inhibitory effects of erythromycin. Evelyn et al. (1984a) have shown that surface disinfection can sterilize the egg surface; however, the doses used were significantly higher $\left(500 \mathrm{mg} \mathrm{l}^{-1}\right)$ than those used in the field $(100 \mathrm{mg}$ $\left.1^{-1}\right)$, and the disinfecting technique used was much more rigorous. It is hoped that further analysis of data from the trial reported here will help to clarify this question. In addition, histological examination of embryonated eggs, alevins and parr from injected and uninjected fish is planned to evaluate possible teratogenic or deleterious effects of erythromycin on the developing embryo and fry, as observed by Hicks \& Geraci (1984) in rainbow trout receiving the drug orally.

As an interesting postscript to this trial, the progeny from 1 injected and 2 uninjected brood females were maintained in clean conditions and monitored for evidence of Renibacterium infection using an IFAT stain on kidney smears. These brood fish had been diagnosed as heavily infected based on the observation of large numbers of fluorescing bacteria on IFAT-stained smears of ovarian fluid. Within 6 mo of hatching, large numbers of bacteria were observed in fingerlings from both of the uninjected broodstock, and gross pathological changes indicative of BKD were seen in moribund and dead fish. In contrast to this, very few bacteria were seen in the kidney smears of fingerlings from the injected fish at 6 mo and gross signs of the disease are still lacking at 10 mo post-hatching. This evidence suggests that the injection procedure is effective although it may not completely prevent vertical transmission of $R$. salmoninarum.

Acknowledgements. The cooperation and encouragement of Dr D. Groves and the staff of Seaspring Salmon Farms Ltd were greatly appreciated. G. Prosperi-Porta and J. Ketcheson provided valuable technical assistance.

\section{LITERATURE CITED}

Austin, B. (1985). Evaluation of antimicrobial compounds for the control of bacterial kidney disease in rainbow trout, Salmo garidneri Richardson. J. Fish Dis. 8: 209-220

Bruno, D. W., Munro, A. L. S. (1986). Observations on Renibacterium salmoninarum and the salmonid egg. Dis aquat. Org. 1: $83-87$

Bullock, G. L., Leek, S. L. (1986). Use of erythromycin in reducing vertical transmission of bacterial kidney disease. Vet. Hum. Toxicol., Suppl. 1: 18-20 
Bullock, G. L., Stuckey, H. M., Mulcahy, D. (1978). Corynebacterial kidney disease: egg transmission following iodophore disinfection. Fish Health News 7. 51-52

Difco Supplementary Literature (1968). Difco Laboratories Detroit, Michigan

Evelyn, T P. T (1988). Bacterial kidney disease in British Columbia, Canada: comments on its epizootiology and on methods for its control on fish farms. In: Aqua Nor '87 International Conference, Norwegian Fish Farmers Association and Sales Organisation, 7001 Trondheim Norway, p. $5 i-57$

Evelyn, T. P. T., Ketcheson, J. E., Prosperi-Porta, L. (1984a). Further evidence for the presence of Renibacterium salmoninarum in salmonid eggs and for the failure of povidone-iodine to reduce the intra-ovum infection rate in water-hardened eggs. J. Fish Dis. 7. 173-182

Evelyn, T P. T., Prosperi-Porta, L., Ketcheson, J. E. (1984b) The salmonid egg as a vector of the kidney disease bacterium, Renibacterium salmoninarum. In: ACUIGRUP (ed.) Fish diseases, 4 th COPRAQ session. EDITORA ATP, Madrid, p. 111-117

Evelyn, T. P. T., Prosperi-Porta, L., Ketcheson, J. E. (1986a). Experimental intra-ovum infection of salmonid eggs with Renibacterium salmoninarum and vertical transmission of the pathogen with such eggs despite their treatment with erythromycin. Dis aquat. Org. 1: 197-202

Evelyn, T P. T., Ketcheson, J. E., Prosperi-Porta, L. (1986b). Use of erythromycin as a means of preventing vertical transmission of Renibacterium salmoninarum. Dis. aquat. Org. 2: 7-11

Evelyn, T. P. T., Prosperi-Porta, L., Ketcheson, J. E. (1986c). Persistence of the kidney disease bacterium, Renibacterium salmoninarum in coho salmon, Oncorhynchus kisutch (Walbaum), eggs treated during and after waterhardening with povidone-iodine. J. Fish Dis. 9: 461-464

Groman, D. B., Klontz, G. W (1983). Chemotherapy and prophylaxis of bacterial kidney disease with erythromycin. J. World Maricult. Soc. 14: 226-235

Hicks, B. D., Geraci, J. R. (1984). A histological assessment of damage in rainbow trout, Salmo garidneri Richardson, fed rations containing erythromycin. J. Fish Dis. 7: 457-465

Riazi, A., Fremat, L. (1988). Serum vitellogenin and yolk proteolipid compiex composition in relation to ovarian growth in rainbow trout Salmo garidneri (Rich.) Comp. Biochem. Physiol 89B 3: 525-529

Wallace, R. A. (1978). Oocyte growthg in non-mammalian vertebrates. In: Richard, E. J. (ed.) The vertebrate ovary. Plenum Press, New York, p. 469-502

Editorial responsibility: Managing Editor; accepted for printing on November 3, 1988 